\title{
The Effect of Specific Human Capital on Firm Performance Improvement
}

\author{
Caifeng Ma* \\ School of Finance and Economics \\ Shandong JiaoTong University \\ Jinan City, China \\ cfhorse@163.com
}

\author{
Yueyun Jiang \\ School of Finance and Economics \\ Shandong JiaoTong University \\ Jinan City, China \\ gingeryy@163.com
}

\author{
Yuanzhen Jiang \\ Graduate School \\ Beijing Institute of Technology \\ Beijing, China \\ gingeryzh@163.con
}

\begin{abstract}
This paper tries to explore the effect of specific human capital on firm performance. Analyzing a lot of literature, referring to various opinions of experts and scholars, three propositions is proposed: The tenure of the general manager is significantly positively related to real performance, is significantly negatively related to abnormal performance, and is significantly positively related to the investment efficiency. That is to say, the specific human capital has authentic and reliable and continuous effect on the improvement of firm performance. It will be tested the association between specific human capital and firm performance using the panel data over 2010 to 2017 for all listed companies in subsequent research.
\end{abstract}

Keywords-Specific Human Capital; Firm Performance; Authenticity; Reliability; sustainability

\section{INTRODUCTION}

How human capital affects firm performance (FP) is a topic of great concern to researchers and business managers. Existing literature (Eric et al, 2013)[1] shows that superior human capital can improve firm performance, and many economists (De Carolis, 2003; Menguc \& Barker 2005; Wang et al, 2009) , found firm-specific human capital ${ }^{\mathbb{1}}$ improve firm performance, from the perspective of corporate operating performance (e.g., net profit and related indicators). However,

This paper was financially supported by the Shandong Social Science Foundation (16CGLJ35, 16CKJJ26)

${ }^{\text {DD }}$ Becker (1964), the founder of human capital theory, distinguishes human capital as general human capital and firm-specific human capital. Specific human capital refers to the application of the knowledge, skills, and capabilities of workers limited to the specific company's applications. Without specific companies and positions, there will be no human capital with a significant drop in value or value. For example, the company's proprietary technical staff, senior management team members and so on. Compared with universal human capital, its characteristics are difficult to copy, difficult to replace and high-value. like underestimating general human capital, scholars or corporate managers may overestimate the role of specific human capital (Campbell et al., 2012)[2]. Then, does the promotion of specific human capital for firm performance have credibility, reliability, and continuity?

At present, there are not many studies on the relationship between specific human capital and firm performance at home and abroad. So far, there has been no study that specific human capital improves firm performance. The literature (Ployhar et al, 2011) found that specific human capital could improve firm performance from the perspective of corporate publicly disclosed business performance[3]. However, corporate earnings manipulation can also inflate or deflate the performance of public disclosure, which may overestimate or underestimate the effect of specific human capital on firm performance. It is difficult to accurately determine the authenticity of the effect of specific human capital on firm performance. Earnings manipulation affects firm performance (Dechow et al., 2010), which may distort the relationship between specific human capital and firm performance. However, professional reputation and supervisory oversight can restrain accrued earnings management behavior in CEO Tenure. It is difficult to accurately determine the reliability of specific human capital for improving firm performance. Theoretically, specific human capital can bring continuous performance advantages to its own companies (Grant, 1996). However, in practice, it depends on the efficiency of the firm's investment in complementary assets (compared with specific human capital) (Campbell et al., 2012)[2]. The higher the efficiency of complementary assets investment, the more effective the specific human capital will be, so that companies obtain a sustained advantage over competitors' performance. We can't accurately determine the persistence of the effect of dedicated human capital on firm performance improvement. 


\section{THE LiTERATURE REVIEW}

Takeuchi et al. (2007) found that companies' investment in human capital can improve their output efficiency. Compared with general human capital, the increase in the value of specific human capital has a special effect on firm performance. It is an important factor that firm performance is better than that of competitors (Acedo et al., 2006). It is also the key to understand its effect on enterprise performance.

From the perspective of the proxy indicators of firm performance, the basic principle of specific human capital research is that its level has different effects on firm performance. For the relationship between the two, Kor (2006) found that companies with high-value human capital had better performance[4]. So what is business performance? Firm performance can be understood from the output of employees, organizations, finances, and markets (Suying Gao, Yuming Zhao, Xiying Peng, 2011)[5]. Financial profit and its derived indicators are the most commonly used indicators for measuring firm performance (Crook et al., 2008)[6], such as net profit, operating profit, and profit from main business operations. Tien-Lei (2012) found that the total amount of human capital (including specific human capital) has a significant positive effect on the firm performance of the total asset profit ratio agent. Xuefen Deng et al. (2012) based on the profit index, combined with the solvency, operating ability, and development ability, concluded that the human capital stock (including specific human capital) is significantly positively correlated with firm performance[7]. In contrast, a meta-analysis of Newbert (2007) found that specific human capital may not be an important determinant of firm performance. It can be seen that there are no stable research conclusions about the effect of specific human capital on firm performance improvement under different performance indicators. This will affect our judgment and understanding of the authenticity of specific human capital for firm performance improvement.

From the proxy indicators of specific human capital, Coff (2002) argues that human capital refers to the knowledge, skills, and abilities that exist in the human body, and that specific human capital attaches to a company or a team to reflect its value. Crook et al. (2011) divided the employees attached to specific human capital into top management teams and core employees ${ }^{1}$, there may be cross-realistic situations[8]. High-level management team's reasonable arrangement of core employees can make the core employees' explicit or implicit knowledge, skills and experience that have a better cash flow contribution to the company's innovative projects, can match the project for better work, and thus make the company get better business performance (Kor \& Mahoney, 2005). It can be seen that the work experience of the senior management team is crucial to the role of corporate-specific human capital. Jinzao $\mathrm{Li}$ and Xiaoming Xu(2008) believed that the separation of powers makes the general manager the real top decision maker. Therefore, the attribute characteristics of the general manager are often used as proxy indicators for

\footnotetext{
(1) The top management team includes board members, general managers, deputy managers, etc.; the core employees refer to the specialized technical engineer, etc.
}

enterprise-specific human capital, especially the term of the general manager. However, Simsek (2007) believed that the role of the general manager attribute on firm performance is complex and can lead to instability in the relationship between them. For example, some scholars have found that firm performance and general manager tenure (Chen Deqi et al., 2011), age size (Antia et al, 2010)[9], salary amount (Li Bin, Guo Cambridge, 2013), shareholding The number (Liu Shaojun, Wan Dayan, 2013) have a significant linear positive correlation; some scholars also believe that the company's performance and the number of shares held by the general manager (Aiqin Yan et al., 2012) and the amount of compensation (Junrui Zhang et al., 2003), management experience (Xiaoming Jian, Wei Li, 2006), age are weakly positively correlated. These research conclusions have led us to feel the unreliable effect of specific human capital on firm performance. We speculate that this may be related to the failure to consider the intentional manipulation (surplus management) of the company's operating performance during the tenure of the general manager. The surplus manipulative of the general manager will distort the business performance of the company's public disclosure, it misleads the understanding of the specific human capital to the reliability of the company's performance improvement effect.

From the nature of the use of research data, Although, Crook (2008) et al. found no significant statistical difference in the positive impact of cross-sectional or panel data on the relationship between specific human capital and firm performance [6]; Wernerfelt (1984) thought that human capital can appreciate with the passage of time, the accumulation of knowledge, skills and experience, and make continuous contributions to firm performance. It can be seen that panel data is more conducive to the capture of the impact of specific human capital on firm performance. However, the literature review found that cross-sectional data is the mainstream of research. On the one hand, Rouse and Daellenbach (1999) believed that cross-section data cannot effectively capture the influence of human capital on firm performance over a longer period of time, which may result in an underestimation of the positive impact of specific human capital on firm performance; The use of cross-sectional data research may include the inertial performance before the acquisition of specific human capital, which may in turn lead to an overestimation of the positive impact of the specific human capital on the firm performance. For example, Yu Ren and Jie Xie (2012) used the cross-section data of non-listed companies to find that "relative to the western region, human capital investment in central China has a greater impact on firm performance,” and there may be limitations to underestimation or overestimation of firm performance. Haozhi Hu (2010) using cross-section data to verify the U-shaped relationship between specific human capital and firm performance from the perspective of sales profit margin, return on net assets, and earnings per share, suggests that the correlation between the two is the trend of first descending and rising.

In short, we take general manager's tenure as the proxy of specific human capital, firm performance is measured with the company's true performance, performance management, and investment efficiency, in order to find out that the authenticity, 
reliability and sustainability of the effect of special human capital on enterprise performance improvement.

\section{The Relationship BetWeEN SPECIFIC Human CAPITAL AND FIRM PERFORMANCE}

\section{A. Selection of Measurement Indicators for Specific Human Capital}

The general manager is the top decision maker of the company and it is necessary to maintain the competitive advantage of the enterprise brought about by specific human capital. Specifically, the general manager establishes a longterm planning and constraint system for specific human capital during his term of office (Cohen \& Levinthal, 1990), does a good job in employee training and development investment (Combs et al, 2006), and make full use of the specific human capital leverage effect to achieve the best business performance (Sirmon et al, 2007). It can be seen that the use efficiency of enterprise-specific human capital is closely related to the tenure of the general manager.

However, the term of the general manager serves as a proxy variable for the value of the specific human capital, and testing the impact on the performance of the company may still have certain limitations. Although companies can use quantify economic contracts such as annual payments, equity, and options to locks in the general manager's term of office and gains the excess benefits of controlling their specific human capital, in the case of information asymmetry, the general manager's ability to control the specific human capital is difficult to accurately measure or capture, and can only be inferred through the public disclosure of operating performance. It is generally believed that the better the company's operating performance, the stronger the ability of the general manager to control specific human capital and the higher the professional reputation. In order to obtain a higher professional reputation during the term of office, the general manager with the incentive to manipulate earnings, and its degree of manipulation of operating results may be related to the length of the term of office. It can be seen that when using the general manager term index to examine the relationship between specific human capital and firm performance, the influence of the general manager on earnings manipulation should be removed to verify the authenticity of the relationship.

At present, the diversification of general manager surplus maneuvers has increased the difficulty in evaluating the relationship between specific human capitals and operating performance. During the term of office, the motives and behaviors of the general manager's earnings manipulation are complex and diverse, and they will exhibit different characteristics along with changes in internal and external factors such as the market environment and the regulatory environment. Schipper (1989) believes that the general manager's earnings manipulation behavior is essentially the management of public disclosure and aims to deliberately intervene in the process of the company's external financial reporting in order to obtain some self-interest (Healy \& Wahlen, 1999). In the case of accrued earnings management, the use of manipulated (publicly disclosed) business performance to study the relationship between specific human capital (general manager tenure) and firm performance may mislead our understanding and judgment of the reliability of the relationship between them (Healy \& Wahlen, 1999).

\section{B. Overcoming the limitation of firm performance measurement indicators}

The enterprise is an overall organization with a variety of highly integrated resources. The publicly disclosed operating results are also the result of the mixed effects of multiple factors. This test examines the relationship between specific human capital and firm performance, and may overestimate or underestimate the positive impact of specific human capital on firm performance (Collis \& Montgomery, 1995). In fact, scholars are always exploring more direct measurement methods of firm performance, mainly including the following two aspects: First, explore from the perspective of strong senior management team compensation. Members of senior management teams who are in a strong position in the enterprise often receive higher salaries than their own contributions, and incur some profits from dedicated human capital that are higher than those of competing companies (Coff, 1997), and disclose in corporate reports. Previously seized and shared by the general manager, this would underestimate the positive impact of specific human capital on firm performance. Therefore, from the perspective of the company's publicly disclosed operating performance, specific human capital may not have high firm performance. The second is the exploration of the limitations of the selection of indicators for firm performance. The publicly disclosed company's performance is the result of comprehensive utilization of different valuable resources (Richard et al, 2009), it is difficult to capture the real impact of different types of human capital on firm performance (Ray et al, 2004). It may overestimate the positive impact of specific human capital on firm performance. Instead, measurement of firm performance on the basis of operating profit can be closer to the competitive advantage of specific human capital under real conditions, and can effectively reflect the performance contribution from specific value chain activities (Crook et al., 2008).

\section{Determination of the relationship between specific human capital and firm performance}

A lot of literature already dedicated that human capital is the dominant resource of an enterprise. Maintaining the longterm sustainability of the advantage resource is a key measure to improve enterprise performance (Barney, 2001; Summer et al., 1994). In fact, regardless of the general human capital or the specific human capital attached to the staff, the knowledge, experience, and skills determine the level of human capital value. The long-term advantage of enterprise performance brought by the increase of human capital value is long-term results of mutual investment between organizations and individuals. For example, employee education experiences (Becker, 1996), enterprise management training (Hambrick \& Mason, 1984), and human capital investment design (Combs et al, 2006) are important drivers of firm performance. However, compared with universal human capital, specific human capital contributes more to firm performance (Dutta et 
al, 2005; Crook et al, 2008)[6]. Because, in the competitive labor market, employees with universal human capital can enter and leave the company freely (Coff, 1997). Therefore, the increase of the value of general human capital can't only improve the performance of the enterprise, but also improve the production efficiency of the competitors. However, the classical literature (Hashimoto, 1981; Glick \& Feuer, 1984) believes that employees who believe that they have specific human capital are more constrained by their mobility. Embedding of individual employees' knowledge and skills that cannot be easily applied in other companies (specific human capital) forms a transaction isolation mechanism for inter-firm specific human capital (Hatch \& Dyer, 2004). Comparing with the universal human capital needed by all competitors, the specific human capital that is basically stuck in the enterprise is difficult to trade freely (Chi, 1994). Therefore, the enterprise-specific human capital can only contribute to the improvement of the production efficiency of its own companies, and has nothing to do with the production efficiency of other companies. When the value of corporatespecific human capital increases with tenure, employees can make effective judgments about whether their value is consistent with corporate strategy (Kor \& Mahoney, 2005). The general manager can also efficiently allocate corporate resources, such as net profit, operating profit, return on assets and market share, to achieve better decisions and improve firm performance. It can be seen that specialized human capital has a positive contribution to firm performance.

\section{CONCLUSION}

Firm performance is divided into financial performance and market performance. From the foregoing analysis, we can see that the financial performance disclosed by the company can be divided into real performance and abnormal performance. This will give us a few questions. Is the positive impact of specific human capital on firm performance real and reliable? Can it be sustained?

First, the authenticity of the effect of specific human capital on firm performance improvement. The longer the tenure of the general manager is, the stronger the ability to control enterprise-specific human capital, the greater the value of specific human capital, and the higher the efficiency of use (Sirmon et al., 2007). At the same time, the long term implied that the general manager's firm performance was recognized by the owner (Chen Deqi et al., 2011) and that the company's real financial performance would be higher (Francis et al., 2008). We speculate that the specific human capital represented by the general manager's tenure is significantly positively correlated with the real performance of the company, and the effect of the specific human capital on the improvement of the company's performance is authentic. Thus, we get:

Proposition 1: The tenure of the general manager is significantly positively related to real performance. That is, the effect of the specific human capital on the improvement of the company's performance is authentic.

The second is the reliability of the effect of specific human capital on firm performance improvement. Considering that the general manager's own capabilities are also part of specific human capital, poor firm performance or performance expectations will affect the evaluation of the professional manager's market and their career prospects (Oyer, 2008). Therefore, during the term of office, the general manager may have the possibility of manipulating operating profits, resulting in abnormal performance. The existing literature shows that there are motivations for managing the business performance during the initial period of the appointment of the general manager (Pourciau, 1993), during his term of service, and before the departure (Fuxiu Jiang, Bing Zhu, Ning Tang, 2013)[10]. However, at present, the professional manager market is becoming more and more mature. Higher specialized human capital management capabilities, professional reputation, and professional experience are necessary conditions for obtaining the advantages of the workplace. Professional reputation is the valuable wealth of the general manager, and it is closely related to future salary, continuous employment, and social status (Deqi Chen et al., 2011). If the profit manipulation of the general manager's term of office is discovered, then the company's stakeholders and headhunters will lose trust in the historical performance of the company's affiliated company, which will result in a huge loss of professional reputation. Therefore, it can be reasonable to speculate that the general manager has incentives to curb earnings manipulations during the term of office, consciously constrain the accrual of earnings management, and make specific human capitals more reliable for improving firm performance. From this, we propose the following conclusion:

Proposition 2: The tenure of the general manager is significantly negatively related to abnormal performance. That is to say, the specific human capital has a reliable effect on the improvement of firm performance.

The third is the persistence of the effect of dedicated human capital on firm performance improvement. Whether specific human capital can bring continuous performance advantages to enterprises depends not only on the efficiency of investment in human capital, but also on the efficiency of complementary assets such as fixed assets (Campbell et al., 2012). Human capital needs to rely on complementary assets to play a greater role. Under the circumstances of entrusted agency, whether the general manager of the core of the senior management team can suppress the over-investment or underinvestment of complementary assets during the term of office is the key to the continuous advantage of the enterprisespecific human capital. There is a literature that the increase in the number of senior executives can curb excessive investment by enterprises (Zhaoguo Zhang et al., 2013). On the contrary, Guoyuan Zhang (2013) believes that under the condition of asymmetric information, executives under pressure of professional reputation are more inclined to assume that the responsibility for loss of investment projects can be evacuated to the next manager. If you choose a project with a short-term long-term loss, there will be excessive investment. Hambrick (1984) believes that the longer the senior executives are, the less innovative they are in decision-making, which may lead to insufficient investment of the company. For example, there is a general lack of investment in listed companies in China (Weixian Zhou, 2010). Paradoxically, executives with longer 
tenure have the urge to increase R\&D investment, which may lead to excessive investment. However, with the increase of creditor supervision awareness, improvement of the intensity of investment disclosure supervision, and improvement of internal corporate governance, these measures can restrict the over-investment or under-investment of corporate executives over a longer period of time. That can increase the investment efficiency of complementary assets, give full play to the advantages of enterprise-specific human capital and bring about a sustained and stable growth in firm performance. For this reason we propose the following conclusion:

Proposition 3: The tenure of the general manager is significantly positively related to the investment efficiency. In other words, the effect of specific human capital on the improvement of firm performance is continuous.

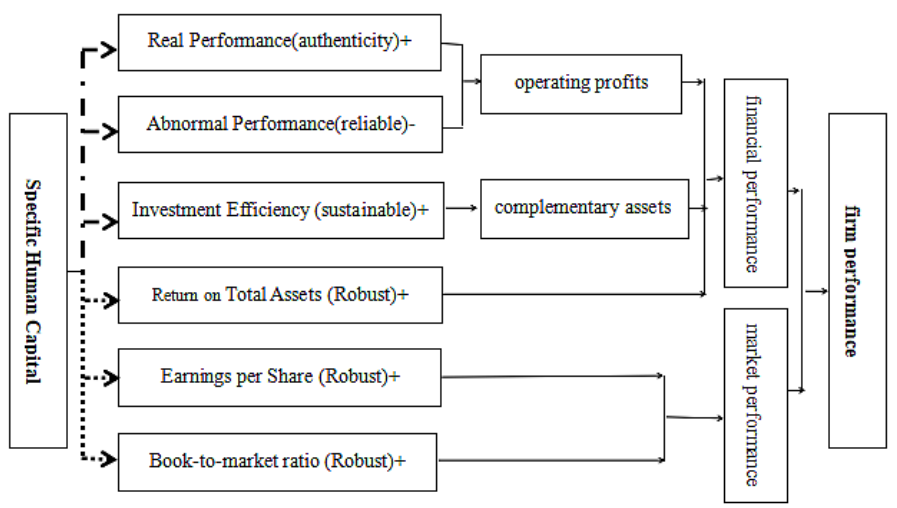

Fig.1. Relationship between Specific Capital and Performance Improvement

\section{REFERENCES}

[1] Eric S, Sanjib C, David V. Firm Productivity Moderated Link between Human Capital and Compensation: The Significance of Task-Specific Human Capital [J]. Human Resource Management, 2013, 52(3): 423439.

[2] Campbell B A, Coff R, Kryscynski D. Rethinking Sustained Competitive Advantage from Human Capital [J]. Academy of Management Review, 2012, 37(3): 376-395.

[3] Ployhart R E, Van Iddekinge C H, Mackenzie W I. Acquiring and Developing Human Capital in Service Contexts: The Interconnectedness of Human Capital Resources[J].The Academy of Management Journal,2011,54(2): 353-368.

[4] Kor Y. Direct and interaction effects of top management team and board compositions on R\&D investment strategy [J]. Strategic Management Journal, 2006, 27(11): 1081-1099.

[5] Suying Gao, Shu-ming Zhao, Xi-ying Peng. Empirical Study on The Relationship Between Human Capital Stock and Firm Performance [J]. Journal of Tianjin University, 2011, 13(1): 1-6.(In Chinese )

[6] Crook T, Ketchen D J, Combs J G, et al. Strategic resources and performance: a meta-analysis. [J]. Strategic Management Journal, 2008,29(11):1141-1154.

[7] Xuefen Deng, Gongxun Huang, Xueying Zhang et al.Empirical Study on The Relationship Between Human Capital Stock and Firm Performance -- a Case Study of High-tech Enterprises [J]. Macroeconomic Research, 2012(1): 73-79.(In Chinese )

[8] Crook T R, Todd S Y, Combs J G, et al. Does Human Capital Matter? A Meta-Analysis of the Relationship between Human Capital and Firm Performance [J].Journal of Applied Psychology, 2011, 96(3): 443-456.

[9] Antia M, Pantzalis C, Park J. CEO decision horizon and firm performance: An empirical investigation [J]. Journal of Corporate Finance, 2010; 16(3): 288-301.

[10] Fuxiu Jiang, Bing Zhu, Ning Tang. Can CEO and CFO Tenure Interchange reduce earnings management?[J]. Management world, 2013(1): 166-175.(In Chinese ). 